\title{
The role of Wnt signaling pathway in carcinogenesis and implications for anticancer therapeutics
}

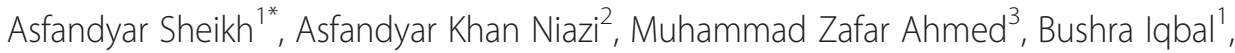 \\ Syed Muhammad Saad Anwer ${ }^{1}$ and Hira Hussain Khan ${ }^{1}$
}

\begin{abstract}
The Wnt proteins are a family of 19 secreted glycoproteins that occupy crucial roles in the regulation of processes such as cell survival, proliferation, migration and polarity, cell fate specification, body axis patterning and self-renewal in stem cells. The canonical pathway has been implicated in a variety of cancers. As such, it is only fair to conclude that therapies targeting the Wnt pathway may play an essential role in the future of anticancer therapeutics, both alone or in conjunction with traditional therapies.
\end{abstract}

\section{Article}

The Wnt signaling pathways represent a group of pathways that comprise of proteins involved in the transduction of signals via cell surface receptors. First identified in 1982 by Nusse in mouse models of mammary cancer, these pathways can be broadly divided into two major groups: canonical and non-canonical, with the differentiating factor being the involvement of $\beta$-catenin (encoded by CTNNB1) in the former $[1,2]$. Both are activated by the binding of a Wnt-protein ligand to a Frizzled family receptor $(\mathrm{Fz})$, which in turn transfers the signal to the intracellular protein, Dishevelled (Dsh) [3].

The Wnt proteins are a family of 19 secreted glycoproteins that are 350-400 amino acids in length [4]. They occupy crucial roles in the regulation of processes such as cell survival, proliferation, migration and polarity, cell fate specification, body axis patterning and self-renewal in stem cells [5]. Mutations of genes involved in this pathway may lead to alteration of the activities of the proteins necessary for signal transduction, a phenomenon that may lead to defects in embryonic development, or may result in a multitude of diseases (e.g. type II diabetes and late onset Alzheimer) in adults [6].

\footnotetext{
* Correspondence: asfandyarsheikh@gmail.com

'Dow Medical College, Dow University of Health Sciences, Baba-e-Urdu Road, 74200 Karachi, Pakistan

Full list of author information is available at the end of the article
}

While the non-canonical pathways are involved in functions such as cytoskeleton development and intracellular calcium homeostasis, the canonical pathway (Figure 1) has greater implications for tumorigenesis [7]. The hallmark protein for the canonical pathway, $\beta$-catenin, plays a role in the activation of transcription factors belonging to the TCF/LEF family [8]. In the absence of Wnt signaling, $\beta$-catenin fails to accumulate in the cytoplasm due to destruction by a degradation complex comprising proteins such as APC, axin, PP2A, GSK3, CK1 $\alpha$ and WTX [8]. Binding of Wnt to $\mathrm{Fz}$ and LRP-5/6 causes disruption of the degradation complex, thereby leading to accumulation of $\beta$-catenin [9]. As such, inappropriate activation of the canonical pathway may lead to elevated levels of intracellular $\beta$-catenin. This may occur as a result of mutations in $\beta$-catenin or other proteins in the pathway, overexpression of Wnt ligands and/or loss of inhibitors or regulatory proteins [10].

The earliest evidence of Wnt involvement in human cancers was with the discovery of the association between APC tumor suppressor gene and $\beta$-catenin [12]. Loss of function mutations in APC are involved in familial adenomatous polyposis, a heritable cancer syndrome, and various forms of sporadic colorectal cancers [13]. Other mutations include those involving axins I and II, both of which are tumor suppressors involved in the downregulation of $\beta$-catenin [14].

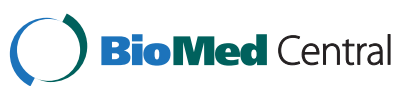




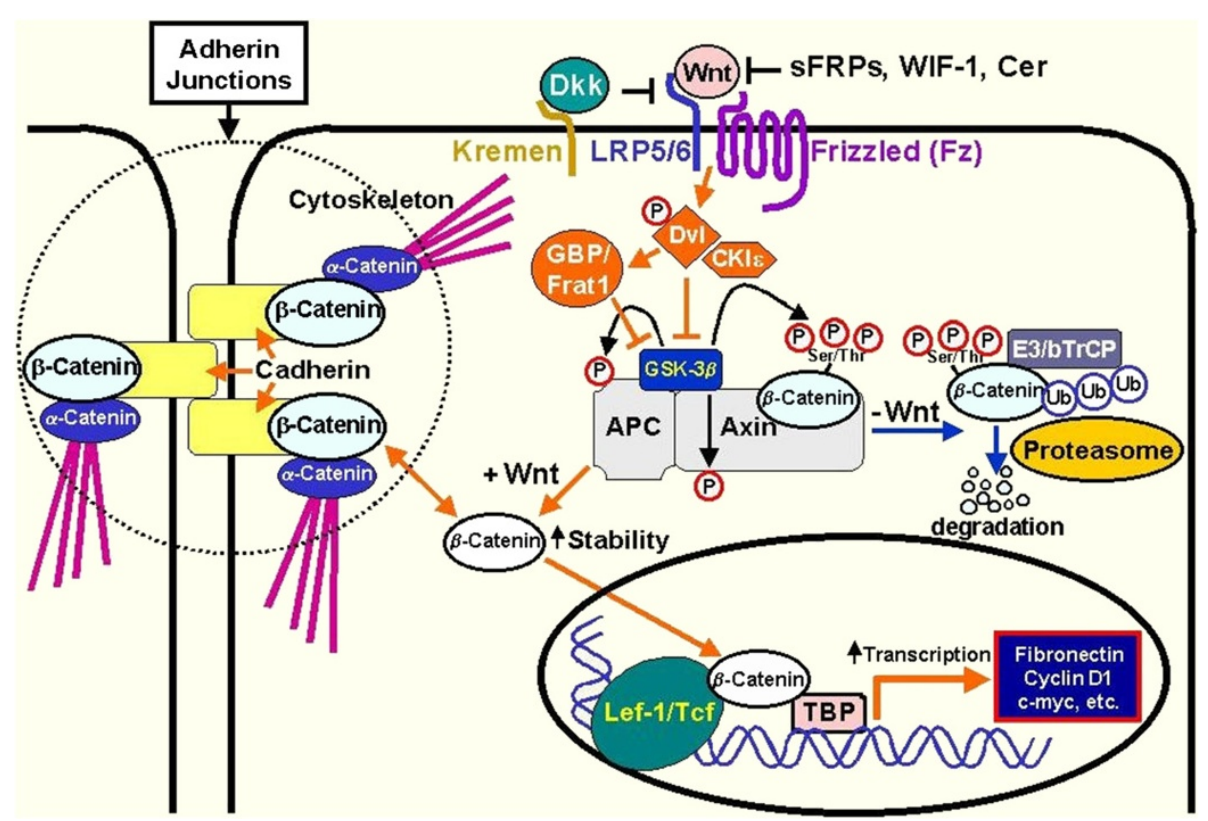

Figure 1 An overview of the canonical Wnt pathway [11].

Inappropriate Wnt signaling has also been implicated in various facets of both benign and malignant breast tumors [15]. Elevated levels of $\beta$-catenin in breast cancer were first demonstrated by Lin et al. in 2000 [16]. The increased levels were found to correlate with increased expression of cyclin D1 [16]. Wnt involvement in the epithelial-mesenchymal transition has also been observed in metastasis of basal-like breast cancer to the lungs [17]. Similarly, increased $\beta$-catenin levels are also detected in melanomas [18]. Inhibition of beta-catenin in metastatic melanoma cell lines has been shown to induce apoptosis, inhibit proliferation, migration and invasion, and decrease chemoresistance [19].

Hepatocellular carcinoma (HCC) has also been identified as a heterogeneous cancer with active Wnt signaling [20]. The dysregulation of Wnt signaling in HCC has been attributed to two distinct molecular classes, namely CTNNB1 and Wnt-TGF $\beta$ [21]. Recent evidence suggests that Glypican-3 (GPC3), a cell surface heparan sulfate proteoglycan, is highly expressed in HCC and may stimulate HCC growth by stabilizing the interaction between Wnt and Fz, thereby causing activation of downstream pathways [22]. Similarly, wnt inhibition has also been shown to inhibit proliferation and induce apoptosis of cultured pancreatic adenocarcinoma (PAC) cells [23]. Wnt signaling may also play a role in drug resistance in PAC via mechanisms such as angiogenesis, highly resistant cancer stem cells or dysregulation of cell cycle and apoptosis [24].

Inappropriate Wnt activation is also critical in certain lung cancers [25]. At least three mechanisms have been identified, namely, overexpression of Wnt effectors such as Dvl, activation of a non-canonical pathway involving JNK and repression of Wnt antagonists such as WIF-1 [25]. Wnt activation has also been implicated in neuronal differentiation in glioblastoma and angiogenesis in gliomas [26,27].

Dysregulation of the canonical pathway in endometrial carcinoma can be attributed to inactivating $\beta$-catenin mutations or downregulation of Wnt antagonists by epigenetic silencing [28]. The wnt pathway is additionally involved with estrogen and progesterone, which further elucidates its significance [28]. Activation of the canonical pathway also exercises effects on prostate cell proliferation, differentiation and epithelial-mesenchymal transition [29]. Elevated levels of $\beta$-catenin have been implicated in prostate cancer progression, due to its association with the androgen receptor [30]. Recent studies have also identified a role of Wnt pathway in Wilm's tumor [31,32].

In view of the above discussion, it is only fair to conclude that therapies targeting the Wnt pathway may play an essential role in the future of anticancer therapeutics, both alone or in conjunction with traditional therapies. Recent reports have grouped potential Wnt inhibitors into three major categories: small molecules, antibodies and peptides [33]. The first category includes low molecular weight compounds that modulate Wnt signaling, in vivo. For example, NSAIDs and celecoxib have been shown to inhibit CTNNB1-dependent transcription in colorectal cells $[34,35]$. XAV939 and pyrvinium are two novel compounds falling in this category [36,37]. XAV939 inhibits tankyrase thereby stabilizing AXIN, whereas 
pyrvinium upregulates CTNNB1 phosphorylation via activation of casein kinase [36,37]. The second category includes blocking antibodies that decrease proliferation and/or induce apoptosis. For example, preclinical studies have already yielded favorable results for a variety of cancers $[38,39]$. This category also includes FZD7-specific antibodies, which have been shown to be beneficial for Wilm's tumor and HCC $[40,41]$. The third category includes peptides such as FZD2 binding proteins [42].

A number of compounds are undergoing clinical trials [43]. For example, OMP-18R5, a monoclonal antibody that targets the Frizzled receptors thereby preventing association with Wnt ligands, is being investigated for solid tumors (NCT01345201) [44,45]. OMP-54 F28 is a fusion protein of the FZD8 ligand-binding domain. It is again being investigated for solid tumors (NCT01608867) [46]. PRI-724 is a small molecule that inhibits interaction between $\beta$-catenin and CBP, whereas LGK974 is another small molecule that inhibits acyltransferase porcupine. Both are being investigated for different forms of cancers $[46,47]$.

In conclusion, with the current era of advancements in anticancer therapeutics, therapies targeting the Wnt pathway do carry some significance [48]. However, it is worthwhile to note here that perturbations of the Wnt signalling pathway in normal cells can be lethal and it has been difficult to identify design specific inhibitory markers that could act on affected cells alone.

\section{Competing interests}

The authors declare that they have no competing interests.

\section{Authors' contributions}

AS conceived the topic and was involved in drafting the initial manuscript. AKN, MZA, BI, SMS and HHK were involved in critically revising the manuscript, listed in decreasing order of their contributions. The authors have read and approved the manuscript. The authors did not receive any financial support/ grant. All authors read and approved the final manuscript.

\section{Author details}

'Dow Medical College, Dow University of Health Sciences, Baba-e-Urdu Road, 74200 Karachi, Pakistan. ${ }^{2}$ Shifa College of Medicine, H-8/4 Islamabad, Islamabad, Pakistan. ${ }^{3}$ Jinnah Medical and Dental College, Karachi, Pakistan.

Received: 21 June 2013 Accepted: 15 April 2014

Published: 22 April 2014

\section{References}

1. Nusse R, Varmus HE: Many tumors induced by the mouse mammary tumor virus contain a provirus integrated in the same region of the host genome. Cell 1982, 31(1):99-109.

2. Rao TP, Kühl M: An updated overview on Wnt signaling pathways: a prelude for more. Circ Res 2010, 106(12):1798-1806.

3. Perrimon N, Mahowald AP: Multiple functions of segment polarity genes in Drosophila. Dev Biol 1987, 119(2):587-600.

4. Cadigan KM, Nusse R: Wnt signaling: a common theme in animal development. Genes Dev 1997, 11(24):3286-3305.

5. Wang J, Sinha T, Wynshaw-Boris A: Wnt signaling in mammalian development: lessons from mouse genetics. Cold Spring Harb Perspect Biol 2012, 4:5.

6. Logan $C Y$, Nusse R: The Wnt signaling pathway in development and disease. Annu Rev Cell Dev Biol 2004, 20:781-810.
7. Polakis P: The many ways of Wnt in cancer. Curr Opin Genet Dev 2007, 17(1):45-51.

8. Komiya $Y$, Habas R: Wnt signal transduction pathways. Organogenesis 2008, 4(2):68-75.

9. MacDonald BT, He X: Frizzled and LRP5/6 receptors for Wnt/beta-catenin signaling. Cold Spring Harb Perspect Biol 2012, 4:12

10. Salim A: Novel anticancer agents in clinical and preclinical trials. Curr Opin Genet Dev 2014, 2(2):38-39.

11. Howard J, Varallo V, Ross D, Roth J, Faber K, Alman B, Gan B: Elevated levels of beta-catenin and fibronectin in three-dimensional collagen cultures of Dupuytren's disease cells are regulated by tension in vitro. BMC Musculoskelet Disord 2003, 4(1):16.

12. Su LK, Vogelstein B, Kinzler KW: Association of the APC tumor suppressor protein with catenins. Science (New York, NY) 1993, 262(5140):1734-1737.

13. Bienz M, Clevers H: Linking Colorectal Cancer to Wnt Signaling. Cell 2000, 103(2):311-320.

14. Salahshor $S$, Woodgett JR: The links between axin and carcinogenesis. J Clin Pathol 2005, 58(3):225-236.

15. Howe LR, Brown AMC: Wnt Signaling and Breast Cancer. Cancer Biol Ther 2004, 3(1):36-41.

16. Lin SY, Xia W, Wang JC, Kwong KY, Spohn B, Wen Y, Pestell RG, Hung MC: Beta-catenin, a novel prognostic marker for breast cancer: its roles in cyclin D1 expression and cancer progression. Proc Natl Acad Sci U S A 2000, 97(8):4262-4266.

17. DiMeo TA, Anderson K, Phadke P, Feng C, Perou CM, Naber S, Kuperwasser C A novel lung metastasis signature links Wnt signaling with cancer cell self-renewal and epithelial-mesenchymal transition in basal-like breast cancer. Cancer Res 2009, 69(13):5364-5373.

18. Damsky William E, Curley David P, Santhanakrishnan M, Rosenbaum Lara E, Platt James T, Gould Rothberg Bonnie E, Taketo Makoto M, Dankort D, Rimm David L, McMahon M, Bosenberg M: ${ }^{2}$-Catenin signaling controls metastasis in braf-activated Pten-deficient melanomas. Cancer Cell 2011, 20(6):741-754.

19. Sinnberg T, Menzel M, Ewerth D, Sauer B, Schwarz M, Schaller M, Garbe C, Schittek $B$ : $\beta$-catenin signaling increases during melanoma progression and promotes tumor cell survival and chemoresistance. PLOS ONE 2011, 6(8):e23429.

20. Nambotin SB, Wands JR, Kim M: Points of therapeutic intervention along the Wnt signaling pathway in hepatocellular carcinoma. Anti Cancer Agents Med Chem 2011, 11(6):549-559.

21. Lachenmayer A, Alsinet C, Savic R, Cabellos L, Toffanin S, Hoshida Y, Villanueva A, Minguez B, Newell P, Tsai HW, Barretina J, Thung S, Ward SC, Bruix J, Mazzaferro V, Schwartz M, Friedman SL, Llovet JM: Wnt-pathway activation in two molecular classes of hepatocellular carcinoma and experimental modulation by sorafenib. Clin Cancer Res 2012, 18(18):4997-5007.

22. Gao W, Ho M: The role of glypican-3 in regulating Wnt in hepatocellular carcinomas. Cancer Rep 2011, 1(1):14-19.

23. Pasca Di Magliano M, Biankin AV, Heiser PW, Cano DA, Gutierrez PJA, Deramaudt T, Segara D, Dawson AC, Kench JG, Henshall SM, Sutherland RL, Dlugosz A, Rustgi AK, Hebrok M: Common Activation of Canonical Wnt Signaling in Pancreatic Adenocarcinoma. PLoS ONE 2007, 2(11):e1155.

24. Cui J, Jiang W, Wang S, Wang L, Xie K: Role of Wnt/beta-catenin signaling in drug resistance of pancreatic cancer. Curr Pharm Des 2012, 18(17):2464-2471.

25. Mazieres J, He B, You L, Xu Z, Jablons DM: Wnt signaling in lung cancer. Cancer Lett 2005, 222(1):1-10.

26. Rampazzo E, Persano L, Pistollato F, Moro E, Frasson C, Porazzi P, Della Puppa A, Bresolin S, Battilana G, Indraccolo S, Te Kronnie G, Argenton F, Tiso N, Basso G: Wnt activation promotes neuronal differentiation of glioblastoma. Cell death disease 2013, 4:e500.

27. Reis M, Czupalla CJ, Ziegler N, Devraj K, Zinke J, Seidel S, Heck R, Thom S, Macas J, Bockamp E, Fruttiger M, Taketo MM, Dimmeler S, Plate KH, Liebner $S:$ Endothelial Wnt/ $\beta$-catenin signaling inhibits glioma angiogenesis and normalizes tumor blood vessels by inducing PDGF-B expression. J Exp Med 2012, 209(9):1611-1627.

28. Dellinger TH, Planutis K, Tewari KS, Holcombe RF: Role of canonical Wnt signaling in endometrial carcinogenesis. Expert Rev Anticancer Ther 2011, 12(1):51-62.

29. Kypta RM, Waxman J: Wnt/beta-catenin signalling in prostate cancer. Urology: Nature reviews; 2012 
30. Yardy GW, Brewster SF: Wnt signalling and prostate cancer. Prostate Cancer Prostatic Dis 2005, 8(2):119-126.

31. Zirn B, Samans B, Wittmann S, Pietsch T, Leuschner I, Graf N, Gessler M: Target genes of the WNT/beta-catenin pathway in Wilms tumors. Genes Chromosomes Cancer 2006, 45(6):565-574.

32. Corbin M, De Reynies A, Rickman DS, Berrebi D, Boccon-Gibod L, Cohen-Gogo S, Fabre M, Jaubert F, Faussillon M, Yilmaz F, Sarnacki S, Landman-Parker J, Patte C, Schleiermacher $G$, Antignac $C$, Jeanpierre $C$ : WNT/beta-catenin pathway activation in Wilms tumors: a unifying mechanism with multiple entries? Genes Chromosomes Cancer 2009, 48(9):816-827.

33. Anastas JN, Moon RT: WNT signalling pathways as therapeutic targets in cancer. Nat Rev Cancer 2013, 13(1):11-26.

34. Dihlmann S, Siermann A, Von Knebel DM: The nonsteroidal anti-inflammatory drugs aspirin and indomethacin attenuate beta-catenin/TCF-4 signaling. Oncogene 2001, 20(5):645-653.

35. Tuynman JB, Vermeulen L, Boon EM, Kemper K, Zwinderman AH, Peppelenbosch MP, Richel DJ: Cyclooxygenase-2 inhibition inhibits c-Met kinase activity and Wnt activity in colon cancer. Cancer Res 2008, 68 (4):1213-1220

36. Huang SM, Mishina YM, Liu S, Cheung A, Stegmeier F, Michaud GA, Charlat O, Wiellette E, Zhang Y, Wiessner S, Hild M, Shi X, Wilson CJ, Mickanin C, Myer V, Fazal A, Tomlinson R, Serluca F, Shao W, Cheng H, Shultz M, Rau C, Schirle M, Schlegl J, Ghidelli S, Fawell S, Lu C, Curtis D, Kirschner MW, Lengauer $C$, et al: Tankyrase inhibition stabilizes axin and antagonizes Wnt signalling. Nature 2009, 461(7264):614-620.

37. Thorne CA, Hanson AJ, Schneider J, Tahinci E, Orton D, Cselenyi CS, Jernigan KK, Meyers KC, Hang BI, Waterson AG, Kim K, Melancon B, Ghidu VP, Sulikowski GA, LaFleur B, Salic A, Lee LA, Miller DM 3rd, Lee E: Smallmolecule inhibition of Wnt signaling through activation of casein kinase 1alpha. Nat Chem Biol 2010, 6(11):829-836.

38. Li X, Placencio V, Iturregui JM, Uwamariya C, Sharif-Afshar AR, Koyama T, Hayward SW, Bhowmick NA: Prostate tumor progression is mediated by a paracrine TGF-beta/Wnt3a signaling axis. Oncogene 2008, 27(56):7118-7130.

39. He B, You L, Uematsu K, Xu Z, Lee AY, Matsangou M, McCormick F, Jablons DM: A monoclonal antibody against Wnt-1 induces apoptosis in human cancer cells. Neoplasia (New York, NY) 2004, 6(1):7-14.

40. Pode-Shakked N, Harari-Steinberg O, Haberman-Ziv Y, Rom-Gross E, Bahar S, Omer D, Metsuyanim S, Buzhor E, Jacob-Hirsch J, Goldstein RS, Mark-Danieli M, Dekel B: Resistance or sensitivity of Wilms' tumor to anti-FZD7 antibody highlights the Wnt pathway as a possible therapeutic target. Oncogene 2011, 30(14):1664-1680.

41. Wei W, Chua MS, Grepper S, So SK: Soluble Frizzled-7 receptor inhibits Wnt signaling and sensitizes hepatocellular carcinoma cells towards doxorubicin. Mol Cancer 2011, 10:16.

42. Zhang Y, Appleton BA, Wiesmann C, Lau T, Costa M, Hannoush RN, Sidhu SS: Inhibition of Wnt signaling by Dishevelled PDZ peptides. Nat Chem Biol 2009, 5(4):217-219.

43. Takahashi K, Yamanaka S: Induction of pluripotent stem cells from mouse embryonic and adult fibroblast cultures by defined factors. Cell 2006, 126(4):663-676.

44. Gurney A, Axelrod F, Bond CJ, Cain J, Chartier C, Donigan L, Fischer M, Chaudhari A, Ji M, Kapoun AM, Lam A, Lazetic S, Ma S, Mitra S, Park IK, Pickell K, Sato A, Satyal S, Stroud M, Tran H, Yen WC, Lewicki J, Hoey T: Wnt pathway inhibition via the targeting of Frizzled receptors results in decreased growth and tumorigenicity of human tumors. Proc Natl Acad Sci U S A 2012, 109(29):11717-11722.

45. Mughal A, Aslam HM, Sheikh A, Khan AM, Saleem S: c-Met inhibitors. Infect Agents Dis 2013, 8(1):13.
46. Pommery N, Henichart JP: Involvement of PI3K/Akt pathway in prostate cancer-potential strategies for developing targeted therapies. Mini Rev Med Chem 2005, 5(12):1125-1132.

47. Manning BD, Cantley LC: AKT/PKB signaling: navigating downstream. Cell 2007, 129(7):1261-1274.

48. Salim A: Novel anticancer agents in clinical and preclinical trials. El Mednifico Jl 2014, 2(2):38-39.

doi:10.1186/1897-4287-12-13

Cite this article as: Sheikh et al:: The role of Wnt signaling pathway in carcinogenesis and implications for anticancer therapeutics.

Hereditary Cancer in Clinical Practice 2014 12:13.

\section{Submit your next manuscript to BioMed Central and take full advantage of:}

- Convenient online submission

- Thorough peer review

- No space constraints or color figure charges

- Immediate publication on acceptance

- Inclusion in PubMed, CAS, Scopus and Google Scholar

- Research which is freely available for redistribution

Submit your manuscript at www.biomedcentral.com/submit
C Biomed Central 